\title{
Evaluation of the Relationship between Organizational Compensation and Employee Output in Five Selected Manufacturing Firms in South- East, Nigeria
}

\author{
Ede, Titus Eguji, Ph.D ${ }^{1 *}$, Mbah, Paulinus Chigozie, Ph.D ${ }^{2}$
}

${ }^{1}$ Department of Sociology and Anthropology, Faculty of Social Sciences Enugu State University of Science and Technology, Enugu
${ }^{2}$ Department of Business Administration, Faculty of Management Sciences Enugu State University of Science and Technology, Enug

DOI: $\underline{10.36347 / \text { sjahss.2020.v08i08.002 }}$

| Received: 16.05.2020 | Accepted: 23.05.2020 | Published: 09.08.2020

*Corresponding author: Ede, Titus Eguji, Ph.D

Abstract

Original Research Article

This study is an evaluation of the relationship between organizational compensation and employee output in five selected manufacturing firms in south-east, Nigeria. The population for the study was five thousand, and eleven employees (5,011). The study sample size was eight hundred and ninety-five (895) respondents. Questionnaire which was validated by experts was the instrument used for data collection. Some of the major findings is that there is a positive relationship between access to training and employee product quality in the five selected manufacturing firms in South-East, Nigeria $(\mathrm{r}=.780 ; \mathrm{p}=.000>0.05, \mathrm{n}=895)$; there is a positive relationship between organizational compensation and employees output in the five selected manufacturing firms in South-East, Nigeria $(\mathrm{r}=.840$; $\mathrm{p}=$ $.000>0.05, \mathrm{n}=895)$. The study concluded that that if employees are well compensated and well trained, it will encourage more productivity and overall output. Consequent upon the findings, some recommendations were made; It is recommended that employees should be given access to continual training of all types just to keep up, firms should invest resources in training and coaching employees, which will, in turn, give their employees a sense of ethical obligation to respond with increased effort, and a desire to stay with the organization to 'repay the debt, Finally, firms should strategically structure their compensation plan accordingly. This can be done informally by asking employees with other companies that you interview about their compensation plan, or more objectively by hiring an outside consulting firm to benchmark their plan against others and advise you on how to adjust it.

Keywords: Organizational Justice; Job Satisfaction and Manufacturing Firms.

Copyright @ 2020: This is an open-access article distributed under the terms of the Creative Commons Attribution license which permits unrestricted use, distribution, and reproduction in any medium for non-commercial use (NonCommercial, or CC-BY-NC) provided the original author and source are credited.

\section{INTRODUCTION}

Most companies want to hire the most qualified employees and keep those employees loyal and productive. To attract and keep their best employees, companies provide a "package" that includes compensation (money), incentives (special perks or rewards for good work), and benefits (valuable options such as health insurance and paid vacation). Since each employee is unique, larger corporations offer a wide range of mix-and-match options to suit individual needs and preferences. As a manager, the organisation may have the option of offering their team members specific incentives based on their type of work and particular areas of interest and need [1].

The basic element of guaranteed pay is the base salary which is paid on an hourly, daily, weekly, bi-weekly, semi-monthly or monthly rate. A base salary is provided for doing the job the employee is hired to do. The size of the salary is determined mainly by the prevailing market salary level paid by other employers for that job, and the performance of the person in the job. Many countries, provinces, states or cities dictate a minimum wage. Employees' individual skills and level of experience leave room for differentiating income levels within a job-based pay structure. In addition to base salary, allowances may be paid to an employee for specific purposes other than performing the job. These can include allowances for transportation, housing, meals, cost of living, seniority, or as payments in lieu of medical or pension benefits. The use of allowances varies widely by country, as well as job level and the nature of job duties [2].

The term compensation represents the exchange between employees and organization; both give something in return for something else. In the past, 
the compensation issues were often confidential and governed by an individual employer's preferences and choices. However, in today's competitive world the compensation policies are more transparent and the employees take their own choices based on the compensation package. Thus, balancing the cost of compensation and retaining the employees have become the most important priority for the organization. The compensation is a substitute word of wages and salaries and it has recently originated. The literature on wages and salaries' is enormous but it considers the issues from a legal viewpoint. However, wages have now become very significant as a cost factor [1]. Compensation is the remuneration received by an employee in return for their contribution to the organization. Compensation management is an organized practice that is important for balancing the work and employee relationship by providing monetary and non-monetary compensation to employees. Compensation includes all form of pay given to the employees which arise from the employment. One of the strapping features of the organizations is compensation management and they used it to attract and retain the most important and worthy assets [1].

The compensation management is considered to be a complex process that requires accuracy and precision and if not carried out properly may lead to employees' dissatisfaction. An ideal compensation policy motivates the employees to work harder and with more determination. It also helps the organizations to set the standards for the job that it is related to, realistic and measurable. Compensation policies should have a sound integration with practices of HRM. One of the key functions of compensation management of any company is to create a hearty competition among the employees in order to attain more efficiently and provide growth opportunities to its employees [3].

Most organisations have long recognized the importance of training in their development and as part of organizational compensation. As new technologies progress, making certain jobs and skills redundant, an increasing emphasis is being placed on the need for a skilled and highly trained workforce for good performance. Many of the jobs being replaced by machines have been of an unskilled nature, and this emphasizes the need for higher education and skills for those wishing to gain employment in the future [4]. Management of employees on matters concerning performance can result in highly complex and emotionfilled decisions. The motivation of the employee is an important factor that may ensure that the employees remain focused on the organization's goals and objectives. This includes work-based and external training. Training involves enabling people to perform their work to the best of their ability, meeting and perhaps exceeding targets and standards [5]. Employees that are trained by their organisations are more involved in the assigned tasks [6]. The employees who are very committed to job assignments as an essential part of their life. After their better performance, they feel satisfied, this nature of job involvement deemed towards self-esteem [7]. After being trained personnel become highly motivated for doing innovative tasks when they feel high involvement in their jobs [8]. Training improves employee performance in human resources as well as the organisation. If employees are wholeheartedly involved in training issues that are directly related to their job, then they try to take initiatives to remove many problems [9]. Involvement in official tasks directly influences employee performance. An effort is an intervening relationship between training and performance. It helps to reconcile the gap between what should happen and what is happening between desired targets or standards and actual levels of work performance [4]. Training need is any shortfall in employee performance or potential performance which can be remediated by appropriate training. There are many ways of overcoming deficiencies in human performance at work, and training is one of them. There have been so many arguments regarding this topic, thus the necessitation of this study.

\section{Statement of the Problem}

The existence of organizational compensation and employee training is a critical issue for the success of an organization. In the world of work, employees and employers have traditionally made a tacit agreement: In exchange for workers ${ }^{e e}$ commitment, organizations would provide forms of value for employees, such as secure jobs and fair compensation. So it is clear that some performance-based rewards are vital in establishing job satisfaction among employees and the improved commitment could improve the level of job responsibility and accountability [8]. Monetary compensation is important, but not sufficient, to keep employees. Non-monetary recognition plays the same role as compensation does. Praise, appreciation, and positive feedback from managers and peers for a job well done is imperative to generate job satisfaction and commitment. Lack of Organizational compensation and adequate training may lead to undesired organizational outcomes such as lower job satisfaction, retaliation, turnover, misbehaviour, low productivity, lower work commitment, poor decision-making procedures and low quality work relationships. As a result of higher expectations and demands on manufacturing firms, the issues of organizational justice and its associated workrelated outcomes are quite relevant to employees working in them. Hence the study evaluated organizational justice and job satisfaction among employees of selected five manufacturing firms in South East, Nigeria.

\section{OBJECTIVES OF THE STUDY}

The specific objectives are

1. To evaluate the relationship between access to training and employees' quality of products in 
five selected manufacturing firms in SouthEast, Nigeria.

2. To ascertain the relationship between organizational compensation and employee output in five selected manufacturing firms in South-East, Nigeria.

\section{Research Questions}

The following research questions have been formulated to guide the study.

1. What is the relationship between access to training and employees' quality of products in five selected manufacturing firms in SouthEast, Nigeria?

2. What is the relationship between organizational compensation and employee output in five selected manufacturing firms in South-East, Nigeria?

\section{LITERATURE REVIEW \\ Conceptual Framework Employee Training}

Training is teaching or developing in oneself or others, any skills and knowledge that relate to specific useful competencies. Training has specific goals for improving one's capability, capacity, productivity, and performance. It forms the core of apprenticeships and provides the backbone of content at institutes of technology (also known as technical colleges or polytechnics). In addition to the basic training required for a trade, occupation or profession, observers of the labour-market recognize as of 2008 the need to continue training beyond initial qualifications: to maintain, upgrade and update skills throughout working life. People within many professions and occupations may refer to this sort of training as professional development [10].

The on-the-job training method takes place in a normal working situation, using the actual tools, equipment, documents or materials that trainees will use when fully trained. On-the-job training has a general reputation as most effective for vocational work. It involves employee training at the place of work while he or she is doing the actual job. Usually, a professional trainer (or sometimes an experienced employee) serves as the course instructor using hands-on training often supported by formal classroom training. Sometimes training can occur by using web-based technology or video conferencing tools [11].

Roberts and Wayne [12] combine the two concepts into one definition thus: "training and development is the act of a continuous effort designed to improve employee's competency and organizational performance". David [13] defined training as an experience, a discipline or systematic action which causes people to acquire new skills and knowledge and predetermined behaviour. It is the provision of skills and knowledge needed for the present job".
Nwachukwu [14], defined training as the organizational effort which is been aimed at helping an employee to acquire basic skills required for the efficient execution of the functions for which he/she was hired". The definition put by Nwachukwu highlighted the acquisition of skill and responsibility for efficient performance. Training is also directed in helping employees to perform better on their current jobs while development represents a future-oriented investment. Reilly [15] defined training as "the development of a person's knowledge, skills and attitudes for a vocational purpose."

Malaolu and Ogbuabor [16] see employee training as essential for an organization's success. Despite the importance of training, a trainer can encounter resistance from both employees and managers. Both groups may claim that training is taking them away from their work. However, a trainer can combat this by demonstrating that training is actually a crucial part of employees' and managers' work. Training is crucial because it educates workers about the effective use of technology, ensures competitive edge in the market, promotes safety and health among employees, creates opportunities for career development and personal growth, an important factor in retaining workers, helps employers comply with laws and regulations, and improves productivity and profitability. The excess of training in organizations is to see how best employees can improve their productivity to ensure that organizational goals are achieved effectively. Enhancing productivity calls for proper and efficient management of both human and material resources of the organization. Most managers recognize training as effective tools for achieving productivity. It is a well-known fact that organizations always focus and point those activities and programs that can help in the achievements of the objective for which such organizations were established.

Off-the-job training method takes place away from normal work situations implying that the employee does not count as a directly productive worker while such training takes place. The off-the-job training method also involves employee training at a site away from the actual work environment. It often utilizes lectures, case studies, role-playing, and simulation, having the advantage of allowing people to get away from work and concentrate more thoroughly on the training itself. This type of training has proven more effective in inculcating concepts and ideas. Many personnel selection companies offer a service that would help to improve employee competencies and change the attitude towards the job. The internal personnel training topics can vary from effective problem-solving skills to leadership training [17].

Traditionally, training and development is meant to improve the skills of the individual or is seen as a benefit provided by the company. By combining 
training and development with innovation management, an organization can better prepare for the looming talent shortage and the uncertainty that the future holds. This uncertainty is heightened with employees (especially ones with high-potential) moving from organizations more regularly. Combining the organization's innovation management with its training and development programme, allows an organization to groom and equip high-potential employees for their future roles in the company. This creates a sense of stability and security. In addition, research has shown that hiring employees externally for key positions cost more and those candidates tend to be less successful than their internally trained counterparts. This all makes a strong case to centralize training and development and innovation management, and place it under the management of the HR department [17].

\section{Employee Product Quality}

Product quality means to incorporate features that have a capacity to meet consumer needs (wants) and gives customer satisfaction by improving products (goods) and making them free from any deficiencies or defects. Product quality mainly depends on important factors like the type of raw materials used for making a product, how well are various production-technologies implemented? Skill and experience of manpower that is involved in the production process, availability of production-related overheads like power and water supply, transport, etc. Product quality has two main characteristics viz; measure and attributes. The group features and characteristics of a saleable good that determine its desirability and can be controlled by a manufacturer to meet certain basic requirements. Most businesses that produce goods for sale have a product quality or assurance department that monitors outgoing products for consumer acceptability [18].

\section{Employee Output}

Output is an assessment of the efficiency of a worker or group of workers in an organization. This is defined as the number of goods and services or waste products that are produced by an employee. With an agreed-upon strategy, an organization can transform and add value to inputs by producing quality outputs (information, products, services, personal accomplishments or reports which is considered the primary activity of most organizations [19]. Employee output shows the capacity of a company to efficiently or inefficiently achieve independent goals. One of the elements that are assessable is the employees' output through the level of their productivity. Several types of research have been introducing various methods to evaluate employee output $[8,17]$. This includes the quality, quantity, knowledge or creativity of individual towards the accomplished works that are in accordance with the responsibility during a specified period- in other words, the assessment systems must have some standard parameters that can be relied upon [17].

\section{Employee Compensation}

Employee compensation is the total amount an employee can expect to receive when working for an organization. There are many different types of compensation packages that an employer will offer employees [17]. Compensation includes wage and/or salary Programmes and structures, for example, salary ranges for job descriptions, merit-based Programmes, bonus-based Programmes, commission-based Programmes, etc. Compensation is a payment to an employee in return for their contribution to the organization, that is, for doing their job. The most common forms of compensation are wages, salaries, and tips [20]. Compensation is usually provided as base pay and/or variable pay. Base pay is based on the role in the organization and the market for the expertise required conducting that role. Variable pay is based on the performance of the person in that role, for example, for how well that person achieved his or her goals for the year. Incentive plans, for example, bonus plans, are a form of variable pay. (Some people might consider bonuses as a benefit, rather than a form of compensation.) Some Programmes include base pay and variable pay. Organizations usually associate compensation/pay ranges with job descriptions in the organization. The ranges include the minimum and the maximum amount of money that can be earned per year in that role [2].

\section{RESEARCH METHODOLOGY Research Design}

This study employed a longitudinal survey research design since it involves the examination of a phenomenon without any attempt to manipulate the study variables and is characterized by the selection of random samples from the population to obtain empirical knowledge of contemporary nature.

\section{Area of the Study}

The area of the present study was selected using manufacturing firms in South-Eastern, Nigeria; South East of Nigeria is one of the six geopolitical zones in the country.

The five selected manufacturing firms in South-Eastern, Nigeria include:

Enugu State: Chitis Ltd (1A Ezillo Street,
Independence Layout, Enugu $)$

Ebonyi State: Vegas Bakery Limited is located at 79 Ogoja Road Abakaliki Ebonyi State.

Anambra State: Amerigo Bakery is located at \#4 Agulu Road Amawbia Awka South, Anambra. 
Imo State:

All Tea-Mate Gold Bakery is a reputable pastry company situated within Umuguma, Owerri Capital Territory in Imo State Nigeria.
Abia State: M.O. NNAJI Bread No. 56 Obohia Road, Aba, Abia State. Nigeria.

Population of the Study

The population of an understudy is shown below:

Table-1: Population Distribution

\begin{tabular}{|l|l|l|l|l|l|}
\hline S/N & Manufacturing firms & Mgt & Senior & Junior & Total \\
\hline 1 & Chitis Ltd Enugu state & 43 & 353 & 534 & 930 \\
\hline 2 & All Tea-Mate Gold Bakery Imo state & 58 & 322 & 602 & 982 \\
\hline 3 & 1. AMERIGO bakeries Anambra state & 41 & 425 & 694 & 1160 \\
\hline 4 & M.O. Nnaji Bakery Abia state & 28 & 215 & 732 & 975 \\
\hline 5 & Vegas Bakery Limited Ebonyi & 38 & 347 & 579 & 964 \\
\hline & Total & $\mathbf{2 0 8}$ & $\mathbf{1 6 6 2}$ & $\mathbf{3 1 4 1}$ & $\mathbf{5 0 1 1}$ \\
\hline
\end{tabular}

Source: Administrative Officers, 2018.

Table 1 above shows that five firms were selected from five states in Southeast Nigeria, which is made up of management, senior and junior staff of the bakery firms which gave a total population of five thousand, and eleven employees $(5,011)$.

\section{Sampling Technique/ Sample size determination}

To determine the sample for the study, the random sampling technique was applied since the population used is a homogenous one. On the basis of this, the population was random into firms registered with MAN and those not registered but have a capital investment of more than N10milion. The study sample size was eight hundred and ninety-five (895) respondents. This sample size is justified because the population was huge and such a sample was sufficient to address the research problem. The actual population was five thousand, eleven employees $(5,011)$ employees. The population of the study was drawn from the three levels of employees in these organizations under study using a simple random sampling method. To determine the adequate sample size, the researcher opts for the Freund and William's statistical formula. In calculating the sample size, the researcher used the statistical formula for selecting a finite population as formulated by Freund and Williams.

$$
\begin{aligned}
& n=\frac{Z^{2} N(p q)}{N(e)^{e}+Z^{2}(p q)} \\
& \text { Where } \mathrm{n}=\text { Sample Size } \\
& \mathrm{N}=\text { The population } \\
& \mathrm{p}=\text { Probability of success/proportion } \\
& \mathrm{q}=\text { Probability of failure/proportion } \\
& \mathrm{Z}=\text { Standard error of the mean } \\
& \mathrm{e}=\text { Limit of tolerable error (or level of significance) } \\
& \qquad \begin{array}{l}
\mathrm{N}=5,011 \\
\mathrm{p}=.5 \\
\mathrm{q}=(1-.5)=.5 \\
\mathrm{Z}=97 \text { percent }=1.98 \\
\mathrm{e}=0.3 \text { percent } \\
(1.98)^{2} \times 5011 \times .5 \times .5
\end{array} \\
& \begin{array}{c}
5011(0.03)^{2}+(1.98)^{2} \times .5 \times .5 \\
\end{array}
\end{aligned}
$$

$$
4911.811
$$

$\frac{4.5099+.9801}{4911.811}$
$=8.49$
$\simeq 894.68$
$\simeq 895$

\section{Instruments for Data Collection}

The main instrument for data collection is a structured questionnaire and in-depth interview (IDI) as a means to explain more from the questionnaire. Data were collected between $25^{\text {th }}$ May- $26^{\text {th }}$ June 2019. Copies of the questionnaire were administered to management, senior and junior of the organizations studied. The questionnaire was divided into two sections, section $\mathrm{A}$ is designed to gather information about the participant characteristics like gender, demographic information, qualification, age, and work experience. While section $\mathrm{B}$ is designed to gather responses of employees on the extent the independent variable affects the dependent variable. The responses generated would be used thereafter for data analysis.

\section{Validity and Reliability of the Instrument}

The face and content validity of the instrument was used by giving out copies of the questionnaire to some experts in research in the Department of Sociology and Anthropology, and they reviewed the contents items of the questionnaire, in-depth interview (IDI) for clarity of words, contents coverage, relevance and effectiveness in measuring the variables under study. To ascertain that the instrument is reliable, the test method was adopted in which 20 copies of the questionnaire were distributed to other firms outside the study; two copies to each firm. These were collected afterward and redistributed after two weeks. The reliability of the two responses was determined using the Spearman rank-order correlation coefficient.

\section{Method of Data Collection}

The questionnaire which constituted part of the instrument for data collection was distributed to the respondents with the aid of five research assistants each 
for the selected manufacturing firm who were properly tutored on the objectives of the study and their expected roles. The questionnaire was administered during working hours. The researcher gave a 5-day interval before the questionnaire was collected for vetting and analysis. A total of 895 copies of the questionnaire were administered. The corrected completed ones were rated reliable and used for the analysis in this study.

\section{Method of Data Presentation and Analysis}

The questionnaire responses were cleaned, grouped into various categories and entered into the SPSS version 20 software to facilitate analysis using descriptive statistics. Frequency distribution tables were used to summarize the data from the respondents. The analyzed data were presented in frequency distributions table and bar charts for ease of understanding and analysis. Data from the questionnaire were analyzed using simple percentages, mean and standard deviation. The data were expressed in scale. Data were presented in tables, percentages, mean and standard deviation.
Pearson Product-Moment Correlation, Fstatistics, and regression analysis were used to test the hypotheses, determine the nature, and strength of the research variables.

\section{Pearson Product-Moment Correlation \\ $\mathrm{r}=\frac{N \sum X Y-\left(\sum Y\right)}{\sqrt{\left[N \sum X^{2}-\left(\sum X\right)^{2}\left[\sum X Y^{2}-\left(\sum Y\right)^{2}\right]\right.}}$

Where:

$\mathrm{r}=$ correlation coefficient

$\mathrm{n}=$ Sample size

$\mathrm{X}=$ Variable $\mathrm{X}$ response

$\mathrm{Y}=$ Variable $\mathrm{X}$ response

\section{Data Analysis, Presentation and Interpretation} Analyses of Research Questions

Research Question 1: What is the relationship between access to training and employee product quality in selected manufacturing firms in SouthEast, Nigeria?

Table-2: Response to the statement on how often my organisation organises training for the employees so that they become qualified to work

\begin{tabular}{|l|l|l|l|c|}
\hline & Frequency & Percent & Mean $(\chi)^{-}$ & Std. \\
\hline Very often & 400 & 48.8 & 3.97 & .245 \\
\hline Often & 386 & 47.1 & 3.52 & .501 \\
\hline Not often & 4 & .5 & 4.00 & .000 \\
\hline Rarely & 30 & 3.7 & 1.55 & .663 \\
\hline Total & $\mathbf{8 0 1}$ & $\mathbf{1 0 0 . 0}$ & $\mathbf{3 . 6 6}$ & $\mathbf{. 6 7 3}$ \\
\hline
\end{tabular}

Source: Field Survey, 2020

A look at table 2 indicates that 400 respondents out of 801 representing 48.8 percent were of the opinion to very often that their organisation organises training for the employees so that they become qualified to work with a mean score of (3.97) and standard deviation of (.245). 386 respondents representing 47.1 percent with mean score of (3.52) and standard deviation of (.501) responded often, 4 were of the opinion not often representing .5 percent with mean score of (.400) and standard deviation of (.400) that their organisation organise training for the employees so that they become qualified to work, 30 respondents representing 3.7 percent with mean score of (1.55) and standard deviation of (.663) responded rarely. The implication of this finding is that the bakery industries organise frequent training for their employees which induces them to have quality experiences. This implies that high productivity will be increased and employee retention will also be high.

Table 2 indicated that 400 respondents out of 801 representing 48.8 percent were of the opinion that very often their organisation organised training for the employees so that they become qualified to work with a mean score of (3.97) and standard deviation of (.245). 386 respondents representing 47.1 percent with mean score of (3.52) and standard deviation of (.501) responded often, 4 were of the opinion not often representing .5 percent with mean score of (.400) and standard deviation of (.400) that their organisation organised training for the employees so that they become qualified to work, 30 respondents representing 3.7 percent with mean score of (1.55) and standard deviation of (.663) responded rarely. The implication of this finding is that the bakery industries organised frequent training for their employees which induces them to have quality experiences and high productivity will be assured and employee retention will also be high.

Research Question 2: What is the relationship between organizational compensation and employee output in selected five manufacturing firms in South-East, Nigeria? 
Table-3: Response to the statement on how employee recognition improved the quality of products and services in the organization

\begin{tabular}{|l|c|c|c|c|}
\hline & Frequency & Percent & Mean $(\chi)$ & Std. \\
\hline $\begin{array}{l}\text { Through employee } \\
\text { commitment. }\end{array}$ & 632 & 77.1 & 3.81 & .499 \\
\hline $\begin{array}{l}\text { Addition to extra time } \\
\text { outside working periods. }\end{array}$ & 162 & 19.8 & 3.43 & .588 \\
\hline Punctuality to work. & 4 & .5 & 3.00 & 1.155 \\
\hline Reduced absenteeism. & 22 & 2.7 & 1.27 & .456 \\
\hline Total & $\mathbf{8 0 1}$ & $\mathbf{1 0 0 . 0}$ & $\mathbf{3 . 6 6}$ & $\mathbf{. 6 7 3}$ \\
\hline
\end{tabular}

Source: Field Survey, 2020

Table 4.21 indicated that 632 respondents out of 801 representing 77.1 percent were of the opinion that how employee recognition improved the quality of products and services in the organization with a mean score of (3.85) and standard deviation of (.492). 282 respondents representing 34.4 percent with a mean score of (3.56) and standard deviation of (.564) responded on how employee recognition improved the quality of products and services in the organization. 4 were of the opinion that high employee recognition improved the quality of products and services in the organization. .5 percent with a mean score of (3.00) and standard deviation of (.1.178) that how employee recognition improved the quality of products and services in the organization, 30 respondents representing 3.7 percent with a mean score of (1.67) and standard deviation of (.711) with I don't know. The implication of this finding is that employee recognition improved the quality of products and services in the organization. Recognizing the most productive employees also drive co-workers to be productive themselves.

Table-4: Response to the statement on the Ways to reduce job stress in the bakery industry

\begin{tabular}{|l|c|c|c|c|}
\hline & Frequency & Percent & Mean $(\chi)^{-}$ & Std. \\
\hline Reduce work load & 32 & 3.9 & 1.125 & .163 \\
\hline Democratic style of leadership. & 32 & 3.9 & 2.708 & .336 \\
\hline There is improved technology. & 156 & 19.0 & 2.978 & .258 \\
\hline There is a schedule of duty. & 600 & 73.2 & 3.908 & .176 \\
\hline Total & $\mathbf{8 0 1}$ & $\mathbf{1 0 0 . 0}$ & $\mathbf{3 . 6 6}$ & $\mathbf{. 6 7 3}$ \\
\hline
\end{tabular}

Source: Field Survey, 2020

Table 4 indicated that 32 respondents out of 801 representing 3.9 percent were of the opinion that reducing workload are the ways to reduce job stress in the bakery industry with a mean score of (1.125) and standard deviation of (.163). 32 respondents representing 3.9 percent with mean score of (2.708) and standard deviation of (.258) responded that Democratic style of leadership the Ways to reduce job stress in bakery industry, 156 were of the opinion that there is improved technology which are the Ways to reduce job stress in bakery industry 19.0 percent with mean score of (2.978) and standard deviation of (.258) and that there is schedule of duty which are the Ways to reduce job stress in bakery industry 600 respondents representing 19.0 percent with mean score of (2.978) and standard deviation of (.176). This shows that the schedule of duty reduces job stress in the bakery industry, working in an industry like the bakery is usually stressful and if the job is not scheduled, workers might breakdown as a result of too much stress.

\section{Test of Hypotheses}

Hypothesis One

$\mathbf{H}_{\mathbf{0}}$ There is no positive relationship between access to training and employee product quality in five selected manufacturing firms in SouthEast, Nigeria.

$\mathrm{H}_{1} \quad$ There is a positive relationship between access to training and employees' product quality in selected manufacturing firms in South-East, Nigeria.

\begin{tabular}{|l|c|c|c|r|}
\hline \multicolumn{5}{|c|}{ Model Summary } \\
\hline $\begin{array}{l}\text { Mod } \\
\text { el }\end{array}$ & $\mathrm{R}$ & $\begin{array}{c}\text { R } \\
\text { Square }\end{array}$ & $\begin{array}{c}\text { Adjusted R } \\
\text { Square }\end{array}$ & $\begin{array}{c}\text { Std. Error of } \\
\text { the Estimate }\end{array}$ \\
\hline 1 & $.880^{\mathrm{a}}$ & \multicolumn{2}{|c|}{.780} & \multicolumn{2}{c|}{.779} & .08062 \\
\hline \multicolumn{4}{|c|}{ a. Predictors: (Constant), ORG, THE, FAC,IDE,HOW } \\
\hline
\end{tabular}




\begin{tabular}{|l|l|r|r|r|r|c|}
\hline \multicolumn{7}{|c|}{ ANOVA $^{\text {a }}$} \\
\hline \multirow{2}{*}{ Model } & $\begin{array}{c}\text { Sum of } \\
\text { Squares }\end{array}$ & Df & $\begin{array}{c}\text { Mean } \\
\text { Square }\end{array}$ & F & Sig. \\
\hline \multirow{2}{*}{1} & Regression & 253.605 & 5 & 50.721 & 480.342 & $.000^{\text {b }}$ \\
\cline { 2 - 7 } & Residual & 5.291 & 814 & .006 & & \\
\cline { 2 - 7 } & Total & 258.896 & 819 & & & \\
\hline \multicolumn{7}{|l}{ a. Dependent Variable: RELA } \\
\hline
\end{tabular}

\section{Where}

RELA = the relationship between access to training and employee product quality in five selected manufacturing firms in South-East, Nigeria.

ORG $=$ How often the organization organizes training for the employees so that they can become qualified to work.

THE $=$ the measure training has been a calculated effort in the organization for increasing employees skills

$\mathrm{FAC}=$ the factors that contribute to the behavioural modification to perform a given task in the organisation IDE $=$ Identification of employees current training and development need for next position

$\mathrm{HOW}=$ How the organisation prepares for in ease employee leaves the organisation.

Level of significance: $\alpha$ at 5 percent

Degree of freedom: $\frac{N-1}{K-N}=\frac{5-1}{895-5}=(890,4)=2.7858$

$\mathrm{F}$ - Tabulated value $=2.7858$

\section{Decision Rule}

If the f-calculated is greater than the ftabulated $\{$ F-cal $>$ F-tab $\}$ reject the null hypothesis $\left\{\mathrm{H}_{0}\right\}$ that the overall estimate is not significant and if otherwise conclude that the overall estimate is statistically significant.

\section{DECISION}

Statistical Criteria \{First Order Test $\}$

Coefficient of Multiple Determinants $\left\{\mathbf{R}^{2}\right\}$

The $\mathrm{R}^{2} \quad\{\mathrm{R}$-Squared $\}$ which measures the overall goodness of fit of the entire regression, shows the value as .780 and adjusted to .779 . This means that $\mathrm{R}^{2}$ suggests that access to training variables accounted for 78.0 percent approximately 78 percent of the variation of the employee's product quality. This indicated that the independent variables explained about 89 percent of the variation in the dependent variable. It showed the goodness of fit. We then concluded from the analysis that the relationship between access to training and employee product quality in five selected manufacturing firms in South-East, Nigeria.

From the result, F-calculated $\{480.342\}$ is greater than the F-tabulated $\{2.7858\}$, that is, Fcal $>\mathrm{F}$ tab. Hence, we reject the null hypothesis $\left\{\mathrm{H}_{0}\right\}$ and accept the Alternative hypothesis which means that the overall estimate has a good fit which also implies that our independent variables are simultaneously significant. We now concluded from the analysis that there is a relationship between access to training and employee product quality in the five selected manufacturing firms in South-East, Nigeria.

\section{Hypothesis Two}

$\mathrm{H}_{0}$ There is no positive relationship between organizational compensation and employee output in five selected manufacturing firms in South-East, Nigeria.

\begin{tabular}{|c|c|c|c|c|c|c|}
\hline \multicolumn{7}{|c|}{ ANOVA $^{\mathrm{a}}$} \\
\hline \multicolumn{2}{|c|}{ Model } & $\begin{array}{l}\text { Sum of } \\
\text { Squares }\end{array}$ & Df & $\begin{array}{l}\text { Mean } \\
\text { Square }\end{array}$ & $\mathrm{F}$ & Sig. \\
\hline \multirow[t]{3}{*}{1} & Regression & 276.255 & 3 & 92.085 & 429.036 & $.000^{\mathrm{b}}$ \\
\hline & Residual & 17.514 & 816 & .021 & & \\
\hline & Total & 293.769 & 819 & & & \\
\hline \multicolumn{7}{|c|}{ a. Dependent Variable: POSI } \\
\hline \multicolumn{7}{|c|}{ b. Predictors: (Constant), REW,HER,ORG,WAY,THE } \\
\hline
\end{tabular}

$\mathrm{H}_{2}$ There is a positive relationship between organizational compensation and employee output in five selected manufacturing firms in South-East, Nigeria.

\begin{tabular}{|l|c|r|r|r|}
\hline \multicolumn{4}{|c|}{ Model Summary } \\
\hline Model & $\mathrm{R}$ & R Square & Adjusted R Square & Std. Error of the Estimate \\
\hline 1 & $.870^{\mathrm{a}}$ & .840 & .840 & .14650 \\
\hline \multicolumn{7}{|c|}{ a. Predictors: (Constant), REW,HER,ORG,WAY,THE } \\
\hline
\end{tabular}


Where

POSI $=$ There is no positive relationship between organizational compensation and employee output in five selected manufacturing firms in South-East, Nigeria.

REW $=$ The employee reward in the organization increases the quality of service.

HER = How employee recognition has improved the quality of products and services in the organization.

$\mathrm{ORG}=$ Organisational commitment increases job involvement by making the work more meaningful

WAY $=$ Ways to reduce job stress in the bakery industry

THE $=$ the extent increase in job satisfaction improves one's pride in his/her duty in the organization.

Level of significance: $\alpha$ at 5 percent

Degree of freedom: $\frac{N-1}{K-N}=\frac{5-1}{895-5}=(890,4)=2.7858$

$\mathrm{F}$ - Tabulated value $=2.7858$

\section{Decision Rule}

If the f-calculated is greater than the $\mathrm{f}$ tabulated $\{$ F-cal $>$ F-tab $\}$ reject the null hypothesis $\left\{\mathrm{H}_{0}\right\}$ that the overall estimate is not significant and if otherwise conclude that the overall estimate is statistically significant.

\section{DECISION}

Statistical Criteria \{First Order Test $\}$

Coefficient of Multiple Determinants $\left\{\mathbf{R}^{2}\right\}$

The $\mathrm{R}^{2}$ \{R-Squared\} which measures the overall goodness of fit of the entire regression, shows the value as .840 and adjusted to .840 . This means that $\mathrm{R}^{2}$ suggests that organizational condition of service variables accounted for 77.7 percent approximately 78 percent of the variation of the employees' output. This indicated that the independent variables explained about 78 percent of the variation in the dependent variable. It showed the goodness of fit. We then concluded from the analysis that there is a positive relationship between organizational compensation and employee output in the five selected manufacturing firms in South-East, Nigeria.

From the result, F-calculated $\{429.036\}$ is greater than the F-tabulated $\{2.7858\}$, that is, Fcal $>$ Ftab. Hence, we reject the null hypothesis $\left\{\mathrm{H}_{0}\right\}$ and accept the Alternative hypothesis which means that the overall estimate has a good fit which also implies that our independent variables are simultaneously significant. We now concluded from the analysis that there is a positive relationship between organizational compensation and employee output in the five selected manufacturing firms in South-East, Nigeria.

\section{Summary of Findings}

1. There is a relationship between access to training and employee product quality in the five selected manufacturing firms in South-East, Nigeria ( $\mathrm{r}$ $=.780 ; \mathrm{p}=.000>0.05, \mathrm{n}=895)$.
2. There is a positive relationship between organizational compensation and employees output in the five selected manufacturing firms in SouthEast, Nigeria $(r=.840 ; \mathrm{p}=.000>0.05, \mathrm{n}=895)$.

\section{CONCLUSION}

Based on the findings, it was observed that there is a positive relationship between access to training and employee product quality, a positive relationship between organizational compensation and employees output in the five selected manufacturing firms in South-East, Nigeria. Therefore, this study concludes that if employees are well compensated and well trained, it will encourage more productivity and overall output.

\section{RECOMMENDATIONS}

Based on the findings in the study, the researcher considered the following recommendations desirable.

1. It is recommended that employees should be given access to continual training of all types just to keep up, firms should invest resources in training and coaching employees, which will, in turn, give their employees a sense of ethical obligation to respond with increased effort, and a desire to stay with the organization to 'repay the debt'.

2. Finally, firms should strategically structure their compensation plan accordingly. This can be done informally by asking employees with other companies that you interview about their compensation plan, or more objectively by hiring an outside consulting firm to benchmark their plan against others and advise you on how to adjust it.

\section{REFERENCES}

1. Bakhshi A, Kumar K, Rani E. Organizational justice perceptions as predictor of job satisfaction and organization commitment. International journal of Business and Management. 2009 Sep;4(9):14554.

2. Henderson RI. Compensation management in a knowledge-based world. Upper Saddle River, NJ: Prentice Hall; 2003.

3. Khan RI, Aslam HD, Lodhi I. Compensation Management: A strategic conduit towards achieving employee retention and Job Satisfaction in Banking Sector of Pakistan. International journal of human resource studies. 2011 Jan 1;1(1):89.

4. Armstrong M. Understand ing training: Human resource management. International Journal of Academic research in Management.2010; 3(3), 257-275.

5. Carrell M R. Human resource management in South Africa. Prentice hall South Africa; 1998.

6. Becker K., Antuar N and Everett C. Implementing an employee performance management system in a nonprofit organization. Nonprofit management and leadership.2011; 21(3), 255-271. 
7. Bright L. Does public service motivation really make a difference on the job between perceptions of support and work attitudes: A meta-analysis; 2008 ?

8. Chevailier R. A manager's guide to improving workplace performance. New York: American Management Association; 2007.

9. Safferstone MJ. Organizational leadership: Classic works and contemporary perspectives. Academic Leadership the Online Journal. 2007; 5(1).

10. Speck M and Knipe C. Why can't we get it right? Designing high-quality professional development for standards-based schools (2nd ed.). Thousand Oaks: Corwin Press; 2005.

11. Ogundele O, Idris A and Ogundipe K.. Entrepreneurship succession problems in Nigeria "s family business; A Threat to Sustainability, European Scientific Journal edition. 2015; 8(7); 145

12. Robert $\mathrm{M}$ and Wayne PN. Treating employees fairly and organizational citizenship behaviour: Sorting the effects of job satisfaction, organisational commitment and procedural justice. Employee responsibilities and rights journal.2016; 1(2), 22-44.

13. David J. Role definition and organisational citizenship behaviour: the importance of the employees' perspective. The Academy of management journal. 2014;4(3), 132-145.
14. Nwachukwu C. Management: Theory and Practice. Africana-Fep- Publisher Limited. Anambra; 2014.

15. Reilly JB. Deontic Justice and organisational Neuroscience. Journal of business ethics.2011; 3(5), 122-145.

16. Malaolu VA and Ogbuabor JE. Training and manpower development, employee productivity and organizational performance in Nigeria: An empirical investigation. International Journal of Advances in Management and Economics. 2013;2(5), 163-177.

17. Paul M. What is employee compensation? Definition and concept. 2018; Retrieved from https://study.com/academy/lesson/what-isemployee-compensation-definition-lessonquiz.html.

18. Gaurav A. What is product quality? Definition meaning importance. 2013; Retrieved from http://kalyancity.blogspot.com/2013/05/what-is-productquality-definition.html.

19. Meredith JR, Mantel Jr SJ, \& Shafer SM. Project management in practice. Wiley Global Education; 2013.

20. Sheri M. Employee benefits and compensation (employee pay). 2009. Retrieved from https://managementhelp.org/payand benefits/index.html. 